\title{
Application of Optimization Models in Prediction of Inland Water Transport Organizations' Profit
}

\author{
Nesterov V.N. \\ Neizvestnaya D.V.
}

Kazan Federal University, Institute of Management, Economics and Finance, Kazan, 420008, Russia

\section{Doi:10.5901/mjss.2014.v5n24p160}

\section{Abstract}

The optimal allocation of scarce resources and the maximization of profit is one of the most important tasks of the transport organizations management. The article's significance is in consideration of ways of optimization of the resources allocation aimed at profit maximization in inland water transport organizations. The authors offered to use time of vessels operation by types of activities as constraints due to optimization, as the period income river companies is rather short period of time. The article shows an example calculation of the optimal allocation of resources to maximize profit on a real example.

Keywords: inland water transport, activity segments, marginal profit, resources, optimization.

\section{Introduction}

The process of various economic phenomena management requires the prediction of results in certain conditions on a on-going basis. To expedite the decision on the choice of optimal management and savings model, the modelling of real processes of business operations is used.

Shipping organizations due to a relatively short income period (5-8 months per year) at the year-round defrayment of expenses and limited resources available need to identify the priority areas to allocate fixed assets, material and financial resources.

River shipping companies should use optimization models of managerial decision making to select the optimal resources allocation in order to maximize marginal profit under uncertainty.

\section{Method}

The economic essence of optimization techniques is in choice of the method of certain limited resources distribution made to achieve maximum or minimum target value. The models of finding the parameters values that provide the extremum of the function subject to constraints imposed on the arguments are called mathematical programming problems. Such problems are widely used for solving problems related to resource allocation, production planning, transport management, etc.

The marginal profit is one of the most significant (for management) performance indexes of segments activity. That is why its maximization is one of the priority tasks of improving performance of the separate segment and the organization in general. A segment is understood as a selected on a certain criteria, relatively independent, capable of generating revenues and incurring expenses part of the organization activity being a basis for preparation of reports for internal and external users.

The formulation of the marginal profit maximization model for organizations of inland water transport can be described by the following formula:

$M R=\sum_{i=1}^{n} \sum_{j=1}^{m} m r_{i j} \cdot x_{i j} \Rightarrow \max$,

where ${ }^{m r_{i j}}$ - marginal profit per 1 machine day of $i$ vessel working at $j$ segment;

$x_{i j}$ - number of machine days worked by $i$ vessel of $j$ segment.

The system of constraints is represented by Formula 2. 


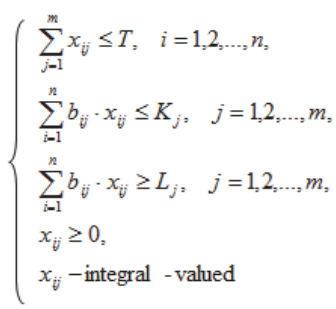

where $T$ - the total time of $i$ vessel operation in all areas of activities. For shipping companies it is limited to the navigation season, that is 200 days at an average; $m$ - number of segments; $b_{i j}$ - carriage volume of $i$ vessel at $j$ segment per time unit; ${ }^{K_{j}}$ - minimal scope of work of $j$ segment. For example, if you have contractual obligations to the contractor for freight services, sale of a certain volume of the extracted non-metallic building materials (NBM), etc. ${ }^{L_{j}}$ maximal limit of work of $\mathrm{j}$ segment. The limit, as a rule, is caused by a restricted demand for products, works, and services of inland water transport organizations. Determination of this limit is made on the basis of demand analysis or marketing researches.

Despite the possibility of splitting the argument expressed in machine days, it seems appropriate to impose constraints on argument integrality; since, practically, it is difficult to observe the vessels "transfer" from one activity to another within one shift.

It should be noted that the use of this model is advisable in cases when the same resources (in this case - river cargo vessels) may be used in several segments of the river company.

\section{Result}

For illustration of the model of maximization of marginal profit of a shipping company through optimal timing of vessels on various segments let us consider the "Kamskaya rechnaya kompaniya" (Kama River Company) LLC.

The fixed assets of the Company include four push tugs of different powers and four barges of different carrying capacities. Specifications of crafts owned by "Kamskaya rechnaya kompaniya" LLC ("KRK" LLC.) are presented in Table 1.

Table 1. Specification of the crafts owned by "KRK" LLC

\begin{tabular}{|c|c|c|c|}
\hline Tug name & Power, h.p. & Barge name & Carrying capacity, $t$ \\
\hline Dunaysky 43 & 1340 & Barzha-81300 & 5000 \\
\hline OT-816 & 800 & Barzha-422 & 4460 \\
\hline Mekhanik Grafsky & 800 & Barzha-423 & 4460 \\
\hline Volgar-34 & 740 & Barzha-1624 & 3750 \\
\hline
\end{tabular}

The management of the organization faces the task of optimal timing of the vessels in each of the following business segments:

- Transportation of NBM extracted at own expense;

- Transportation of other cargoes (timber);

- Vessel lease.

The limitation of "Kamskaya rechnaya kompaniya" LLC scope of activities caused by a deficiency of the following parameters:

- Limitation of the navigation season, constituting 200 days at an average;

- Limitation of crafts (vessels) available - four tugs with barges.

Thus, the organization during the navigation season has 800 machine days ( 200*4).

In addition, the demand research and analysis of concluded contracts revealed lower and upper limits of the segments scopes.

1. The company has signed contracts for the supply of NBM in the amount of 115 thousand tons before the navigation season. The materials are extracted in Sakony village located at a distance of $172 \mathrm{~km}$ from Kazan. The projected maximum volume of NBC extraction during the navigation season will be 312 thousand tons.

2. Timber cargo transportation market research revealed that the maximum possible amount of carriage will be 70 thousand tons. 
Estimated data on probable volume of different types of cargo transportation in unit time are shown in Table 2.

Table 2. Crafts' producing capacity in unit time

\begin{tabular}{|c|l|c|c|}
\hline \multirow{2}{*}{ Vessel No. Segments } & Delivery of NBM extracted, $\mathrm{t}$ & \multirow{2}{*}{ Other cargo transportation, $\mathrm{t}$} \\
\cline { 2 - 4 } & Crafts & 1 & 2 \\
\hline 1 & Segment No. & 653.7 & 381.2 \\
\hline 2 & push tug Dunaysky 43, barge & 550.62 & 319.87 \\
\hline 3 & push tug OT-816, barge & 550.62 & 319.87 \\
\hline 4 & push tug Mekhanik Grafsky, barge & 559.7 & 336.33 \\
\hline
\end{tabular}

The data on vessel marginal profit obtained from different segments of activity per one machine day are presented in Table 3.

Table 3. Crafts' marginal profit in unit time tous.RUR/machine days

\begin{tabular}{|c|l|c|c|c|}
\hline Vessel No. Segments & \multirow{2}{*}{ Delivery of NBM extracted } & \multirow{2}{*}{ Other cargo transportation } & Lease \\
\cline { 2 - 5 } & Crafts & 1 & 2 & 3 \\
\cline { 2 - 5 } & Segment No. & 31 & 29.5 & 15 \\
\hline 1 & push tug Dunaysky 43, barge & 28.5 & 27 & 12 \\
\hline 2 & push tug OT-816, barge & 29 & 28 & 12 \\
\hline 3 & push tug Mekhanik Grafsky, barge & 29 & 27 & 11 \\
\hline 4 & push tug Volgar-34, barge & \multicolumn{2}{|}{} \\
\hline
\end{tabular}

An optimization model of timing of vessels owned by "Kamskaya Rechnaya Kompaniya" LLC is constructed according types of activities on the basis of the original data.

The objective function of marginal profit maximization will be as follows:

$M R=31 \cdot x_{1,1}+29,5 \cdot x_{1,2}+15 \cdot x_{1,3}+28,5 \cdot x_{2,1}+27 \cdot x_{2,2}+12 \cdot x_{2,3}+29 \cdot x_{3,1}+28 \cdot x_{3,2}+$

$+12 \cdot x_{3,3}+29 \cdot x_{4,1}+27 \cdot x_{4,2}+11 \cdot x_{4,3} \Rightarrow \max$

Let us present the constraints by the following system of inequalities:

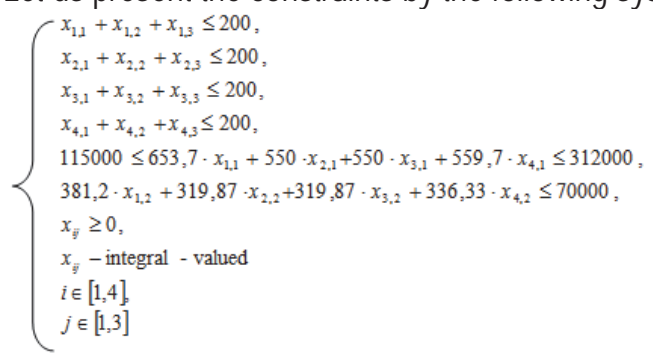

The constructed matrices and the results of optimization are shown in Tables 4-6.

Table 4. Crafts' producing capacity. bij matrix tones/machine days

\begin{tabular}{|c|c|c|c|}
\hline Crafts $\quad$ Segments & Delivery of NBM extracted, $\mathrm{t}$ & Other cargo transportation, $\mathrm{t}$ & Lease, days \\
\hline push tug Dunaysky 43, barge & 653.7 & 381.2 & - \\
\hline push tug OT-816, barge & 550.62 & 319.87 & - \\
\hline push tug Mekhanik Grafsky, barge & 550.62 & 319.87 & \\
\hline push tug Volgar, barge & 559.7 & 336.33 & - \\
\hline Total scope of activity of segment j & 311724 & 64294 & 62 \\
\hline Minimal scope of activity of segment j & 115000 & & \\
\hline Maximal scope of activity of segment $\mathrm{j}$ & 312000 & 70000 & \\
\hline
\end{tabular}


Table 5. Marginal profit in unit time. mrij matrix thous.RUR/machine days

\begin{tabular}{|c|l|c|c|c|}
\hline Vessel No. & Segments & Delivery of NBM extracted & Other cargo transportation & \multirow{2}{*}{ Lease } \\
\cline { 2 - 5 } & Crafts & 1 & 2 & 3 \\
\cline { 2 - 5 } & Segment No. & 31 & 29.5 & 15 \\
\hline 1 & push tug Dunaysky 43, barge & 28.5 & 27 & 12 \\
\hline 2 & push tug OT-816, barge & 29 & 28 & 12 \\
\hline 3 & push tug Mekhanik Grafsky, barge & 29 & 27 & 11 \\
\hline 4 & push tug Volgar-34, barge & & & \\
\hline
\end{tabular}

Table 6. Crafts' time of work. xij matrix

\begin{tabular}{|l|c|c|c|c|c|}
\hline Crafts & $\begin{array}{c}\text { Segments } \\
\text { Delivery of NBM } \\
\text { extracted }\end{array}$ & $\begin{array}{c}\text { Other cargo } \\
\text { transportation }\end{array}$ & Lease & $\begin{array}{c}\text { Total time of vessel } \\
\text { operation, days }\end{array}$ & $\begin{array}{c}\text { Maximal time of vessel } \\
\text { operation, days }\end{array}$ \\
\hline push tug Dunaysky 43, barge & 138 & 0 & 62 & 200 & 200 \\
\hline push tug OT-816, barge & 194 & 6 & 0 & 200 & 200 \\
\hline push tug Mekhanik Grafsky, barge & 5 & 195 & 0 & 200 & 200 \\
\hline push tug Volgar, barge & 200 & 0 & 0 & 200 & 200 \\
\hline
\end{tabular}

\section{Conclusions}

According to the results of the analysis, providing the most optimal time allocation of vessels operation by segments, the maximum profit margin calculated according to the formula 1 amounts to 22304 thousand rubles. In this case, all push tugs will be busy transporting the extracted NBM. The push tug "Volgar" will be busy in this segment for the entire period of the navigation season. The tugs "Dunaysky-43" and OT - 816 will be also engaged the most of navigation time in this segment - 138 days and 194 days, respectively. The tug "Mekhanik Grafsky" most of the navigation time (195 days) will be busy with the transportation of other cargoes, and 5 days - with the transportation of NBM. It is advisable to offer the most powerful vessel "Dunaysky 43" for lease for 62 days. The volume of transported NBM will amount to 311,724 tons. The volume of other cargo will be 64,294 tons with the planned level of demand.

Thus, economic-mathematical modelling can help inland water transport organizations to optimize the vessels work by the types of activities, which will maximize profits.

\section{References}

Asay, H.S., Libby, R., Rennekamp, K. (2013) Do features that associate management with the message increase the persuasiveness of disclosures? Working Paper, The University of lowa, Cornell University, University of Illinois at Urbana-Champaign.

Blume L., Simon C.P. Mathematics for economists. W.W. Norton \& Company, 1994. - 898 p.

Bamber, L.S., Jiang, J., Petroni, K.R., Wang, I.Y. Comprehensive income: Who's afraid of performance reporting? (2010) Accounting Review, 85 (1), pp. 97-126.

Barua, A., Lin, S., Sbaraglia, A.M. Eaming management using discontinued operations (2010) Accounting Review, 85 (5), pp. $1485-$ 1509.

Battini, D., Boysen, N., Emde, S. Just-in-Time supermarkets for part supply in the automobile industry (2013) Journal of Management Control, 24 (2), pp. 209-217.

Safiullin L.N., Shaidullin R.N., Ulesov D.N., Shigabieva A.M. Essential features of small and medium business. Life Science Journal 2014; 11(6s): $392-395$.

Berger, P.G., Hann, R.N. Segment profitability and the proprietary and agency costs of disclosure (2007) Accounting Review, 82 (4), pp. 869-906.

Kaspina Rosa Grigoryevna, Khapugina Lyudmila Sergeevna, Zakirov Elmir Akdasovich Employment of activity-based costing in the process of company business model generation // Life Science Journal, 2014; 11(8s). - Pp. 356-359.

Botosan, C.A., Harris, M.S. Motivations for a change in disclosure frequency and its consequences: An examination of voluntary quarterly segment disclosures (2000) Journal of Accounting Research, 38 (2), pp. 329-353.

Gallyamova D. Kh. (2014). Development of Globalization in the Modern Economy // World Applied Sciences Journal 30 (9): pp. 11601165.

Brynzér, H., Johansson, M.I. Design and performance of kitting and order picking systems (1995) International Journal of Production Economics, 41 (1-3), pp. 115-125.

Díaz-Madroñero, M., Mula, J., Peidro, D. A review of discrete-time optimization models for tactical production planning (2014) International Journal of Production Research 52 (17), pp. 5171-5205. 
Safiullin L.N., Kramin M.V., Kramin T.V., Timiryasova A.V. Drivers of economic growth and investment attractiveness of Russian regions. Life Science Journal 2014; 11(6s), pp. 526 - 530.

Emde, S., Boysen, N. Optimally routing and scheduling tow trains for JIT-supply of mixed-model assembly lines (2012) European Journal of Operational Research, 217 (2), pp. 287-299.

Takayama A. Analytical Methods in Economics. Harvester Wheatsheaf, 1994. - 640 p. 